\title{
Techno-Economics of Pyramid Shape Solar-Biomass Hybrid Drying of Nutmeg
}

\author{
D.R. Pavane ${ }^{1 *}$, Y.P. Khandetod ${ }^{2}$ and A.G. Mohod $^{1}$ \\ ${ }^{I}$ Department of EOES, CAET, Dr. BSKKV, Dapoli. M.S., India \\ ${ }^{2} C A E T$, Dr. BSKKV, Dapoli. M.S., India \\ *Corresponding author
}

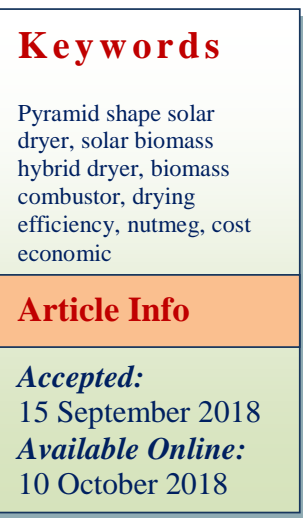

\begin{abstract}
A B S T R A C T
Preservation of fruits, vegetables, and food are essential for keeping them for a long time without further deterioration in the quality of the product. Solar drying has been used since time immemorial to dry plants, seeds, fruits, meat, fish, wood, and other agricultural, forest products. The aim of the dryer is mainly for the welfare of the marginalized and poor farmers those who can't afford hi-tech facilities and equipment's to preserve their agricultural products. Conventionally, nutmeg (Myristica fragrans) is dried in the sun or in kitchen fire place utilizing the heat radiated from the stove drying requires more time and affected its quality. In order to maintain quality and to increase sufficient temperature in the drying chamber during rainy season and cloudy hours, a pyramid shape solar biomass dryer assisted with biomass combustor was designed. Power of the pyramid shape scientists experimented by making model pyramids and placing different types of food in them. The food stayed in good condition much longer than expected. 1959, engineer Karel Drbal did a similar experiment with blunt razor blades. It was found that the blades actually became sharp again when stored in pyramid. The pyramid may act as a resonant cavity that drives out water molecules from the steel edge by resonant action on water, thereby dehydrating the razor blade edge. Resonant effects on water that use microwave energy is a known form of electromagnetic dehydration. Thus, rapid dehydration of the blade may help restore sharpness to steel blades more quickly. A pyramid shape solar biomass dryer assisted with biomass combustor was designed and developed for drying of nutmeg in batch. A pyramid shape solar-biomass hybrid dryer was designed and fabricated in the Dr. BSKKV, Dapoli. With the objective to evaluate the pyramid shape solar -biomass hybrid dryer for nutmeg in rainy season in view to drying hours in a day and to compensate over the use of conventional energy sources for drying of agricultural produce. At no load test without biomass combustor the average temperature in the pyramid shape solar dryer was found to be $60.46{ }^{\circ} \mathrm{C}$ at corresponding ambient temperature of $33.23^{\circ} \mathrm{C}$, solar radiation 570.65 $\mathrm{W} / \mathrm{m}^{2}$, relative humidity $31.10 \%$, in the winter season of December 2017. The average temperature of pyramid shape solar dryer was found to be $64.32{ }^{\circ} \mathrm{C}$ at ambient temperature of $37.30{ }^{\circ} \mathrm{C}$, relative humidity $30.45 \%$, solar radiation $650.45 \mathrm{~W} / \mathrm{m}^{2}$ during the month of March 2017. At no load test pyramid shape solar biomass hybrid dryer the average temperature in the solar biomass hybrid dryer was found to be $55.84{ }^{\circ} \mathrm{C}$ at corresponding ambient temperature of $27.16{ }^{\circ} \mathrm{C}$, solar radiation $239.21 \mathrm{~W} / \mathrm{m}^{2}$, relative humidity $87.58 \%$, in the winter season of December 2017. The average moisture content of nutmeg sample reduced from 613 to $7.8 \%$ (db) in $19 \mathrm{~h}$. Average drying rate was found to be 0.2564 to $0.0005 \mathrm{gm} / 100 \mathrm{gm} \mathrm{bdm} \mathrm{min}$, respectively. The maximum efficiency of biomass combustor and pyramid shape solar-biomass hybrid dryer was found to be 74.84 and 29.10 per cent.
\end{abstract}




\section{Introduction}

Nutmeg is the seed of Myristrica fragrans, and major cultivation of this tree spice is centred around Ernakulam district in Kerala, India. In Konkan region of Maharashtra production of nutmegs is 12,000 tons per year. The quality of this spice is dependent on proper drying. Sun drying and kitchen fire drying are the methods employed for the drying of nutmeg in Kerala. In Konkan region high amount of rainfall ranges between 3500$4500 \mathrm{~mm}$ (June to September). In rainy season large amount of nutmeg available but drying of these fruits is so difficult due to high amount of rainfall. It is also cultivated on small scale in Andhra Pradesh, Assam, Karnataka, Goa and Konkan region of Maharashtra state.

Nutmeg has tremendous potential in the spice industry, as flavour in food and also as ingredient in many values added products. Due to medicinal properties, it is used immensely in the pharmaceutical industry. Oil, oleoresin and fixed oil are extracted from dried nutmeg. Dried nutmeg is of great importance in international trade and is used in the preparation of its extractives and volatile oils. Care has to be taken in each of these process as these operations help in the conservation of the basic qualities like aroma, flavour, pungency, colour, appearance etc. of nutmeg and mace for which they are valued. Among the various operations drying remains the most important step (Krishnamoonhy and Rema, 2011). Colour plays an important role in deciding the commercial value of nutmeg and mace and it has been established that its scarlet red colour is due to the pigment lycopene (Gopalakrishnan et al., 1980). Solar drying process is interrupted during cloudy or rainy days and also at night. Thus, a combination of mixed mode dryer using solar as main input and biomass combustor as auxiliary source of thermal energy will compensate for the absence of the solar radiation. To reduce the drying time and for efficient utilization of locally available biomass for air heating and freely available solar energy, a hybrid solar biomass drying system will be the best option.

In Konkan region, Acacia auriculiformis (Subabul) is abundantly available and can be used as a feed material for biomass combustion for hot air generation. Also, solar energy is available throughout the year except rainy days. Biomass assisted air heating system retrofitted to solar pyramid dryer with extend drying hours and serve the purpose of continuous drying. The biomass combustor cum hot air generator retrofitted to solar pyramid dryer system was designed mainly to complement the solar operation of the dryer, and to sustain the drying process even during cloudy weather. However, it can also be used to extend the period of drying beyond sunshine hours, and perhaps during night as well, while drying high value addition crops.

Driers in general can be easily classified into different types, depending on mode of heat supply, design case, and handling of the feedstock etc. of acceptance. The design is suitable for small-scale industries because it is easy and inexpensive to construct, simple to run and can produce a good quality of products under favourable climatic conditions. Hybrid drying powered by biomass and solar energy is a potentially important option for small-scale operations since it combines the advantages of drying systems operated by solar energy alone and those operated by biomass alone. For commercial producers, this factor limits its ability to dry a produce when there is not adequate solar radiation. Madholpa and Ngwalo (2007) reported the rate of drying of pineapple in biomass mode of operation of dryer operation was higher than that of solar mode. Rincon et al., (2012) indicated the power consumption of the dryer 
was $240 \mathrm{~W}$ when it worked with the solar system and $260 \mathrm{~W}$ when it worked with biomass. Leis, et al., (1999) reported a drier, which used a biomass burner for air heating and running blower through electricity correspond to a thermal output of $112 \mathrm{~kW}$. This paper evaluates the techno economic performance of the pyramid shape solar biomass hybrid dryer for drying of nutmeg on both solar with biomass mode and shade drying, for comparison.

\section{Materials and Methods}

The pyramid shape solar dryer mainly consisted of a cover of UV stabilized acrylic sheet mounted on a triangular frame. The pyramid shape solar dryer was constructed with mild steel and painted black for absorbing more solar radiation to increase the temperature inside the dryer. The main components of the pyramid shape solar dryer was a pyramid structure, chimney, pipes, angles, end frame, lateral support, cover material, drying trays, north wall and chimney and exhaust fan. Pyramid shape solar-biomass hybrid system was consisting of pyramid shape solar dryer and biomass combustor. pyramid shape solar dryer of size $2.3 \times 2.3 \mathrm{~m}$ was used for drying of $25 \mathrm{~kg}$ nutmeg kernel. Biomass combustor cum hot air generator for producing hot air retrofitted to the pyramid shape solar dryer was used during test run as in rainy season.

The technical specifications of pyramid shape solar dryer for nutmeg drying $(25 \mathrm{~kg} / \mathrm{batch})$ are given in Table 1 and 2.

Experiment of drying of nutmeg was conducted in pyramid shape solar biomass hybrid drying and shed drying system in statistical design FRBD. Freshly harvested nutmeg fruits (Myristica fragrans) Konkan Sugandha variety was selected and collected from the Dr. BSSKV, Konkan Krishi
Vidyapeeth, Dapoli. Fully ripened nutmeg fruits were used for experiment.

Techno-economic feasibility of pyramid shape solar biomass hybrid drying system

For the success and commercialization of any new technology, it is essential to know whether the technology is economically viable or not. Therefore, an attempt was made to determine economic of the pyramid shape solar biomass hybrid dryer. The following assumptions/ considerations were taken for carrying out economic analysis of pyramid shape solar biomass hybrid drying system. The area of pyramid shape solar dryer is 6.3 $\mathrm{m}^{2}$. The capacity of the pyramid shape solar biomass hybrid dryer is $25 \mathrm{~kg} \mathrm{batch}^{-1}$. The total finished product (nutmeg) produced per batch at 11 per cent moisture was $10 \mathrm{~kg}$. The average purchase price of freshly harvested nutmeg was Rs. $450 \mathrm{~kg}^{-1}$. Discounting rate was assumed to be 10 per cent as compared to bank lending rate of interest.The average selling price of the nutmeg seed was Rs.720 $\mathrm{kg}^{-1}$. The annual repair and maintenance cost is Rs.5470 considering replacement of acrylic sheet after 3 years and expenditure towards painting and others.

\section{Net present worth (NPW)}

The difference between the present value of all returns and the present money require making an investment is the net present worth.

$N P W=\sum_{t=1}^{t=n} \frac{B_{t}-C_{t}}{(1+i)^{t}}$

Where,

$\mathrm{C}_{\mathrm{t}}=$ Cost in each year

$\mathrm{B}_{\mathrm{t}}=$ Benefit in each year

$\mathrm{t}=1,2,3 \ldots \ldots \ldots \ldots \ldots . . \mathrm{n}$

$\mathrm{i}=$ discount rate 


\section{Benefit cost ratio}

This is the ratio obtained when the present worth of the benefit stream is divided by the present worth of the cost stream. The mathematical benefit-cost ratio can be expressed as:

Benefit-cost ratio $=\sum_{t=1}^{\sum_{t=1}^{t=n} \frac{B_{t}}{(1+i)^{t}}} \frac{C_{t}}{(1+i)^{t}}$

Where,

$\mathrm{C}_{\mathrm{t}}=$ Cost in each year

$\mathrm{B}_{\mathrm{t}}=$ Benefit in each year

$\mathrm{t}=1,2,3 \ldots \ldots \ldots \ldots \ldots . . \mathrm{n}$ (year)

$\mathrm{i}=$ discount rate

\section{Payback period}

The payback period is the length of time from the beginning of the project until the net value of the incremental production stream reaches the total amount of the capital investment. The payback period of the project is estimated by using the straight forward formula:

$$
P=\frac{I}{E}
$$

Where,

$\mathrm{P}=$ Payback period of the project in years,

$\mathrm{I}=$ Investment of the project in rupees and

$\mathrm{E}=$ Annual net cash revenue in Rs.

\section{Results and Discussions}

No load testing during summer season (December)

The average temperature and relative humidity at different locations inside pyramid shape solar dryer during the winter season with corresponding ambient parameters were recorded to evaluate the pyramid shape solar biomass dryer without product during winter and summer season were depicted in Figure 2 to 5 , respectively.

The data presented in Figure 2 showed that during winter season, the average peak temperature inside pyramid shape solar dryer with respect to time achieved its peak value at $13 \mathrm{~h}$ and was found to be $60.47{ }^{\circ} \mathrm{C}$ with corresponding ambient temperature, relative humidity and solar intensity were $33.23{ }^{\circ} \mathrm{C}$, 31.10 per cent, $570.65 \mathrm{~W} \mathrm{~m}^{-2}$, respectively. It was observed that the maximum temperature inside pyramid shape solar dryer was found to be $60.46{ }^{\circ} \mathrm{C}$ at top of pyramid shape solar dryer followed by middle tray $59.50{ }^{\circ} \mathrm{C}$ and bottom tray $58.45^{\circ} \mathrm{C}$ at $13.00 \mathrm{~h}$. The increased in temperature at top tray could be attributed to the maximum direct radiation reaching the top surface and consequent temperature rise in pyramid shape solar dryer by convection heat transfer to air inside the dryer (Fig. 3). The temperature inside pyramid shape solar biomass hybrid dryer with respects to time achieved its peak value at $13.00 \mathrm{~h}$ and found to be $55.84{ }^{\circ} \mathrm{C}$ with corresponding ambient temperature, relative humidity and solar intensity were $28.16{ }^{\circ} \mathrm{C}, 77.58$ per cent, $239.21 \mathrm{Wm}^{-2}$, respectively. The average temperature variation inside pyramid shape solar biomass hybrid dryer was found in between 28.16 to $54.15{ }^{\circ} \mathrm{C}$ during day time when the system operated on biomass mode up to $10.00 \mathrm{~h}$.

\section{No load testing during summer season (March)}

Figure 4 revealed that the maximum temperature inside pyramid shape solar dryer achieved its peak value $66.43{ }^{\circ} \mathrm{C}$ at $13.00 \mathrm{~h}$ with corresponding ambient temperature of $37.30{ }^{\circ} \mathrm{C}$ and solar intensity $650.45 \mathrm{Wm}^{-2}$. The 
average temperature inside pyramid shape solar dryer was found to be $64.32{ }^{\circ} \mathrm{C}$ with corresponding ambient temperature $37.30{ }^{\circ} \mathrm{C}$ and solar intensity $650.45 \mathrm{~W} \mathrm{~m}^{-2}$. It was observed that, the maximum temperature inside the pyramid shape solar dryer was $66.43{ }^{\circ} \mathrm{C}$ at top tray followed by middle tray $64.92{ }^{\circ} \mathrm{C}$ and bottom tray $62.59{ }^{\circ} \mathrm{C}$ (Fig. 5). The average relative humidity inside pyramid shape solar dryer was found to be 16.72 per cent with corresponding average ambient relative humidity 30.45 per cent, average ambient temperature $37.30{ }^{\circ} \mathrm{C}$ and solar intensity $650.45 \mathrm{~W} \mathrm{~m}^{-2}$. The average relative humidity of a day inside pyramid shape solar dryer at top, middle and bottom tray respectively was found to be 17.23, 18.17 and 19.85 per cent, respectively.

No load testing of pyramid shape solar biomass hybrid dryer (June)

The data presented in Figure 6 showed that during rainy season cloudy days by using solar energy with hot air generated by biomass combustor. The average day temperature inside the pyramid shape solar biomass hybrid dryer at top, middle and bottom tray were found to be $55.84{ }^{\circ} \mathrm{C}, 54.18{ }^{\circ} \mathrm{C}$ and $53{ }^{\circ} \mathrm{C}$, respectively. The temperature inside pyramid shape solar biomass hybrid dryer with respects to time achieved its peak value at $13.00 \mathrm{~h}$ and found to be $55.84{ }^{\circ} \mathrm{C}$ with corresponding ambient temperature, relative humidity and solar intensity were $28.16{ }^{\circ} \mathrm{C}, 77.58$ per cent, $239.21 \mathrm{Wm}^{-2}$, respectively. Figure 7 showed that the minimum relative humidity during day time when dryer was operated solar energy and biomass energy was found to be inside the pyramid shape solar biomass hybrid dryer at 39.42 per cent at the top tray of followed by middle tray 40.31 per cent and bottom tray 40.53 per cent during day time and achieved its peak minimum value at $13.00 \mathrm{~h}$ with corresponding ambient relative humidity and solar intensity were 77.58 per cent and 239.21
$\mathrm{Wm}^{-2}$ respectively. The average relative humidity of a day inside the pyramid shape solar biomass hybrid dryer at top, middle and bottom tray, respectively were found to be $48.83,48.54$ and 47.88 per cent. The minimum relative humidity inside the dryer was found at the bottom of the pyramid shape solar biomass hybrid dryer.

\section{Economics of pyramid shape solar biomass hybrid dryer for drying of nutmeg}

The economic feasibility of pyramid shape solar biomass hybrid dryer for drying of nutmeg was calculated by considering initial investment, average repair and maintenance cost, cost of raw material and selling price of the material after drying. Based on the study, the average parameters were calculated for economic analysis of nutmeg depicted in Table 3 and 4. The capacity of the solar biomass hybrid system was $25 \mathrm{~kg}$ batch- 1 . The total finished product produced per batch at 11 per cent moisture was $5 \mathrm{~kg}$. The average purchase price of freshly harvested nutmeg was Rs.450 kg-1. Discounting rate was assumed to be 10 per cent as compared to bank lending rate of interest. The average selling price of the nutmeg seed was Rs.720 $\mathrm{kg}^{-1}$. On the basis of average parameters drawn on the basis of experimental results. Economics of SBHD for drying of nutmeg, the different economic parameter of SBHD are summarized in Table 5.

\section{Net present worth}

The present worth of total cash inflow and outflow for drying of nutmeg kernels under pyramid shape solar biomass hybrid dryer was calculated and found to be Rs. 54700.00. Net resent worth for nutmeg kernels is presented in Table 3. The net present worth of total cash inflow and outflow for drying of nutmeg kernels under pyramid shape solar biomass hybrid dryer was found to be Rs. 747727.08. 
Table.1 Technical specifications of pyramid shape solar dryer for nutmeg drying $(25 \mathrm{~kg} / \mathrm{batch})$

\begin{tabular}{|c|c|c|c|}
\hline S. $\mathbf{N}$. & Particulars & Specifications & Material \\
\hline 1. & Aperture area, $\mathrm{m}^{2}$ & 8.74 & - \\
\hline 2. & Base of dryer, $m$ & 2.3 & - \\
\hline 3. & Height of dryer, $m$ & 1.51 & - \\
\hline 4. & Drying tray area, $\mathrm{m}^{2}$ & $\begin{array}{c}6.32 \\
(2.3,1.8,1.35,0.87)\end{array}$ & MS \\
\hline 5. & Number of trays & 04 & MS angle \\
\hline 7. & $\begin{array}{l}\text { Slant height of pyramid, } \\
\mathrm{m}\end{array}$ & 1.82 & - \\
\hline 8. & Cover, UV stabilized & $4 \mathrm{~mm}$ & Acrylic sheet \\
\hline 9. & Chimney & $\begin{array}{c}1 \text { Nos., } \varnothing 0.15 \mathrm{~m}, \mathrm{H} \\
=0.35 \mathrm{~m}\end{array}$ & 20 SWG MS \\
\hline 10. & Fresh air vent area, $\mathrm{m}^{2}$ & 0.05 & - \\
\hline 11. & $\begin{array}{l}\text { Exhaust Fan, single phase, } \\
40 \mathrm{Wp}, 1400 \mathrm{rpm}\end{array}$ & 1Nos, Brushless AC & - \\
\hline 12. & Door & $2.3 \mathrm{~m} \times 1.5 \mathrm{~m}$ & MS angle \\
\hline 13. & North wall & $\mathrm{H}-1.51 \mathrm{~m}, \mathrm{~B}-2.3 \mathrm{~m}$ & MS sheet \\
\hline
\end{tabular}

Table.2 Technical specifications of biomass combustor cum hot air generator

\begin{tabular}{|c|l|c|}
\hline S. N. & \multicolumn{1}{|c|}{ Particulars } & Specifications \\
\hline 1. & Biomass combustor inner diameter, m & 0.15 \\
\hline 2. & Biomass combustor outer diameter, m & 0.18 \\
\hline 3. & Biomass combustor height, m & 0.17 \\
\hline 4. & Diameter of burner, m & 0.10 \\
\hline 5. & Height of burner, m & 0.09 \\
\hline 7. & No. of secondary air vents & 08 \\
\hline 6. & Height of ash chamber, m & 0.05 \\
\hline 8. & Diameter of ash chamber, m & 0.18 \\
\hline 9. & Area of grate, $\mathrm{m}^{2}$ & 0.028 \\
\hline 10. & Height of grate from bottom, m & 0.06 \\
\hline 11. & Adjustable primary air vent, $\mathrm{m}^{2}$ & 0.02 \\
\hline 12. & Support stand, m & 0.10 \\
\hline 13. & Number of fire tubes & 25 \\
\hline 14. & Diameter of fire tube, m & 0.05 \\
\hline 15. & Height of fire tube, m & 1.0 \\
\hline 16. & Height of flue gas chimney, m & 2 \\
\hline 17. & Diameter of flue gas chimney, m & 0.15 \\
\hline & & \\
\hline
\end{tabular}


Table.3 Computation of cost of operation of nutmeg kernels in pyramid shape solar biomass hybrid dryer

S. $\mathbf{N}$.

1

2

3

4

5

6

7

a Net present worth, Rs

b Benefit- cost ratio

c Payback period

Initial investment (Rs)

Economic indicators
Description

Annual use no. of batches

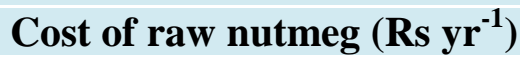

Cost of labour for drying ( ${\left.\operatorname{Rs~} \mathrm{yr}^{-1}\right)}^{-1}$

Operation and maintenance cost $\left(\mathrm{Rs}_{\mathrm{yr}} \mathrm{-}^{-1}\right)$

Total dried product (kg)

Total cost of finishade product
Nutmeg

$54,700.00$

30.00

9375.00

$18,000.00$

5470.00

300.00

$1,44,000.00$

$5,76,316.32$

2.98

6 month and 12 days

Table.4 Economic analysis of pyramid shape solar biomass hybrid dryer for nutmeg kernels

\begin{tabular}{|c|l|c|}
\hline S.N. & Description & Nutmeg \\
\hline I & Fixed cost & 54700 \\
\hline i) & Initial investment (Rs) & \\
\hline II & Operating cost Rs yr-1 & 9375 \\
\hline i) & Raw material cost & 18000 \\
\hline ii) & Labour cost & 5470 \\
\hline iii) & Repair and maintenance cost & 7020 \\
\hline iv) & Cost of fuel & 1440 \\
\hline v) & Electricity charges & $41,305.00$ \\
\hline vi) & Total & \\
\hline
\end{tabular}

Fig.1 Details of isometric view of pyramid shape solar-biomass hybrid dryer

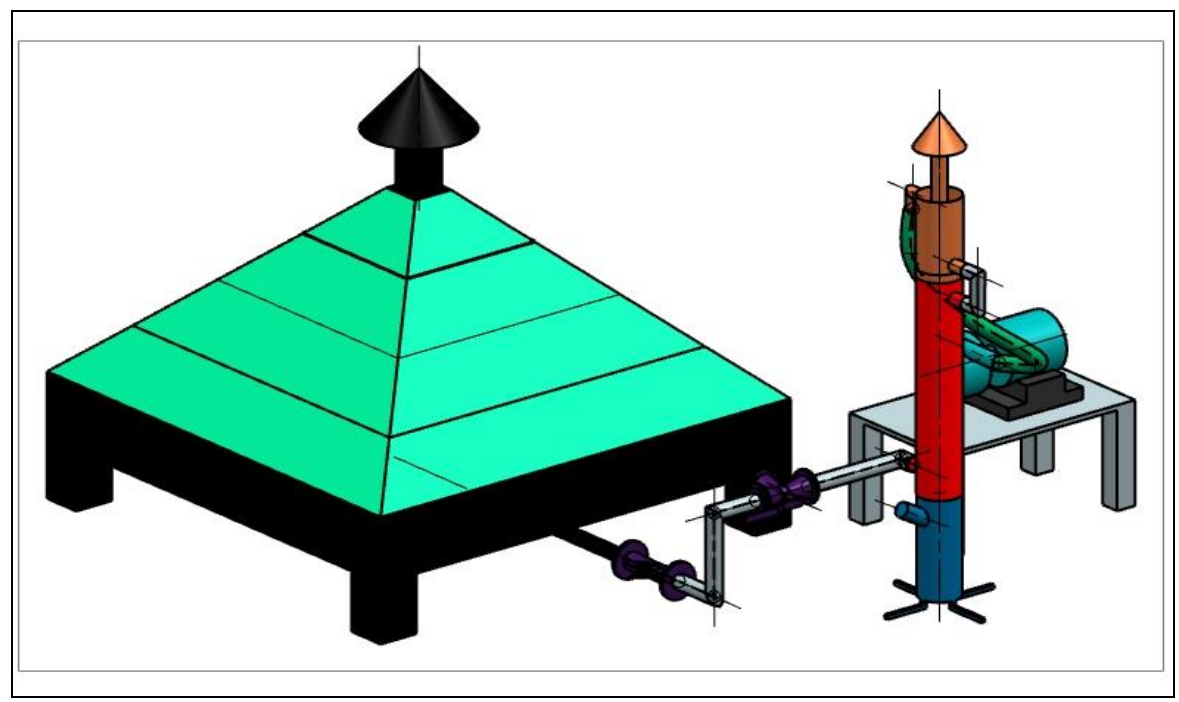


Fig.2 Average temperature variation during no load test in pyramid shape solar dryer of winter season (Dec.) 2017 Fig.3 Average relative humidity variation during no load test in pyramid shape solar dryer of winter season (Dec.) 2017


Fig.4 Average temperature variation during no load test in pyramid shape solar dryer of summer season (March) 2017 Fig.5 Average relative humidity variation during no load test in pyramid shape solar dryer of summer season (March) 2017

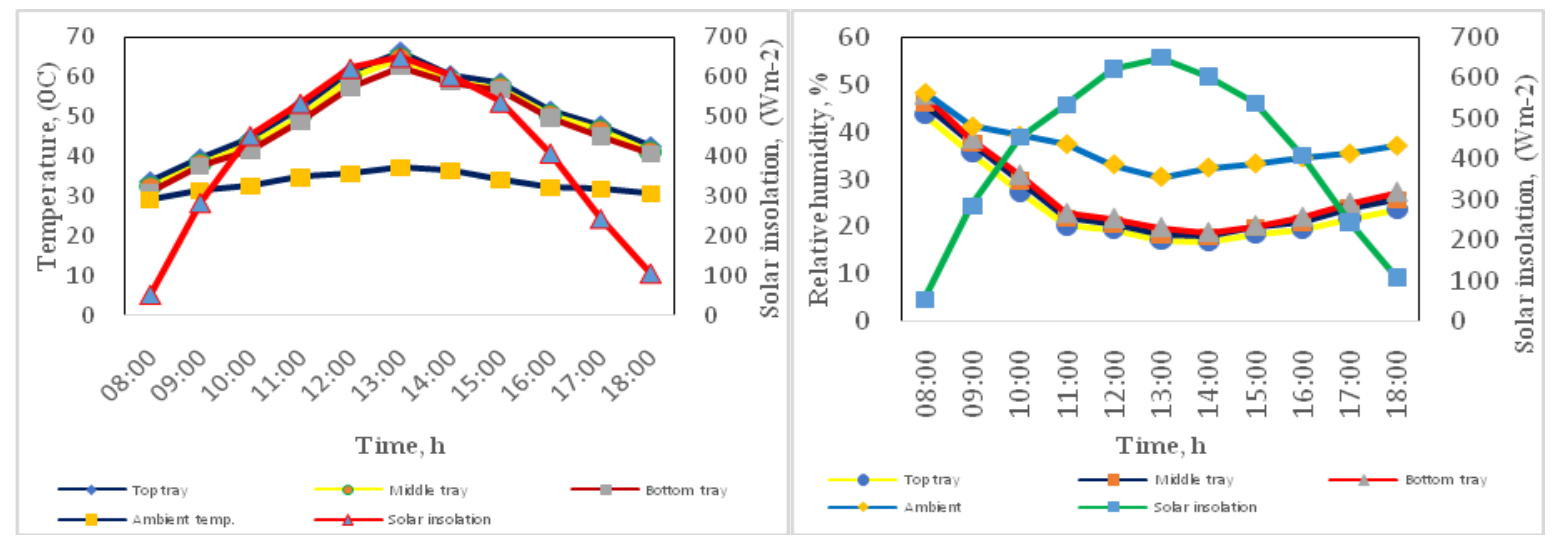

Fig.6 Average temperature variation during no load test in SBHD of monsoon season (June) 2017 Fig.7 Average relative humidity variation during no load test in SBHD of monsoon season (June) 2017

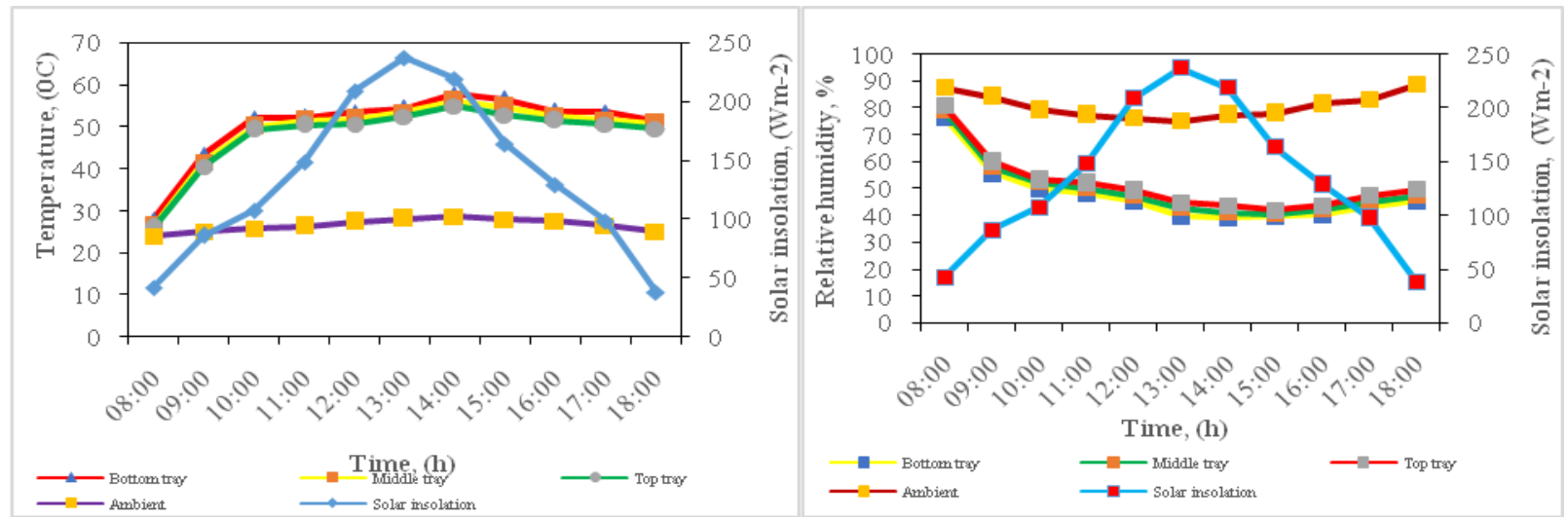


Based on the NPW it could be concluded that that the drying nutmeg kernels in processed form of pyramid shape solar biomass hybrid dryer is an economically a feasible and there is a substantial increase in the income of the nutmeg kernels processor.

\section{Benefit cost ratio}

The benefit cost ratio has been calculated by dividing present worth of benefit stream with the present worth of cost stream and found to be 1.8 for the drying of the nutmeg kernels in pyramid shape solar biomass hybrid dryer.

The $\mathrm{BC}$ ratio of the system was calculated by dividing present worth of benefit stream and present worth of cost stream.

Table 3 revealed benefit cost ratio of nutmeg kernels dried in SBHD and found to be 2.98. Thus, it is concluded that investment is justified and drying of nutmeg kernels is economically viable.

\section{Payback period}

The payback period of pyramid shape solar biomass hybrid dryer for the drying of the nutmeg kernels was found to be 6 month and 12 days for present worth of cash outflow, which revealed the good. Thus it concluded that the drying of nutmeg seems to be economical in pyramid shape solar biomass hybrid dryer.

From all the above economic indicators it was concluded that the drying of nutmeg in pyramid shape solar biomass hybrid dryer found to be more economical. It showed more NPW (747727.08), BC ratio (2.98) and less payback period (6 month and 12 days).

The drying in SBHD seems to be economical because solar energy with biomass energy is freely available.
It is concluded that pyramid shape solar biomass hybrid dryer was able to produce sufficient temperature for drying of nutmeg. The result showed that, temperature inside the pyramid shape solar dryer gets boosted up by 25-30 ${ }^{\circ} \mathrm{C}$ more than the ambient in rainy season. The result also revealed that the nutmeg dried in the pyramid shape solar biomass hybrid dryer was completely protected from rain, insects and dust and the dried nutmegs were high quality compared to shade dried product. From all the above economic indicators it was concluded that drying of nutmeg in pyramid shape solar biomass hybrid dryer found to be more economical than other forms of nutmeg as it showed more NPW (747727.08), BC ratio (2.98) and less payback period (6 month and 12 days). The drying in SBHD seems to be economical because solar energy with biomass energy is freely available.

\section{References}

Gopalakrishnan, M., P. P. Thomas, A. V. Bhat, A. G. Varkey, N. Menon and A.G. Mathew. 1980. Post-harvest technology of nutmeg. In Processing Technology and Marketing. Proceedings of the Third Annual Symposium on Plantation Crops. Indian Society for Plantation crops. Kasargod, India.

Krishnamoorthy, B. and J. Rema. 2011. Harvesting and post-harvest processing. Spice India. 24(5): 4-7.

Leis, H., Muhlbauer, W., and Mulato, S. (1999). Reduction of fire wood consumption in crop driers through combination of solar energy and biomass. In Proceedings of the first Asian-Australian drying conferences (ADC_99), Bali, Indonesia, 24-27 October.

Madhlopa A., G. Ngwalo. 2007. Solar dryer with thermal storage and biomass- 
backup heater. Solar Energy, 81(4): Rincon, S., P. Cuervo and O. Hensel. 2012. 449-462. Drying of Menthaspicata in a dual solar biomass tunnel dryer in Colombia.

\section{How to cite this article:}

Pavane, D.R., Y.P. Khandetod and Mohod, A.G. 2018. Techno-Economics of Pyramid Shape Solar-Biomass Hybrid Drying of Nutmeg. Int.J.Curr.Microbiol.App.Sci. 7(10): 1984-1993. doi: https://doi.org/10.20546/ijcmas.2018.710.229 